International Journal of Current Advanced Research

ISSN: O: 2319-6475, ISSN: P: 2319 - 6505, Impact Factor: SJIF: 5.995

Available Online at www.journalijcar.org

Volume 6; Issue 3; March 2017; Page No. 2347-2348

DOI: http://dx.doi.org/10.24327/ijcar.2017.2348.0006

Research Article

\title{
A STUDY TO ASSESS THE EFFECTIVENESS OF STRUCTURED TEACHING PROGRAMME ON KNOWLEDGE REGARDING BREAST SELF EXAMINATION AMONG GRADE IV STAFFS WORKING AT SELECTED HOSPITAL CHENNAI
}

\section{Hemavathy., Girijabhaskaran and Ningombam Rabita Devi}

Dept of Mental Health Nursing Sree Balaji College of Nursing, Bharath University Tamil Nadu, India

\section{A R T I C L E I N F O}

\section{Article History:}

Received $19^{\text {th }}$ December, 2016

Received in revised form $24^{\text {th }}$ January, 2017

Accepted $12^{\text {th }}$ February, 2017

Published online $28^{\text {th }}$ March, 2017

\section{Key words:}

Structured teaching programme, breast self examination, Group IV.

\begin{abstract}
A B S T R A C T
Cancer as a dreadful disease has a relentless, very painful and debilitating curse and if not treated properly in time, results in death. Breast cancer is the most commonest cancer in women in India. The magnitude of cancer problem is increasing day by day. Breast Cancer, is a malignant growth of breast tissue. Breast cancer is the $3^{\text {rd }}$ most common cancer in the world. In India breast cancer is the $2^{\text {nd }}$ leading cancer in female. American Cancer Society estimates that 1.7 million new cases of invasive breast cancer will be diagnosed in 2014 about 40,910 breast cancer deaths are expected in 2007 Breast self examination is a procedure performed by an individual to physically and visually examine herself for changes in the breast under arm areas of the body. Breast self examination is an important of component health promotion and maintenance. Providing education and encouraging the women to perform breast self examination is recommended to decrease the mortality rates from breast disorders. Thus, this study aimed to assess the effectiveness of structured teaching programme on breast self examination among group IV staffs working at Sree Balaji Medical College and Hospital, Chrompet, Chennai -44. The main purpose of the study was to assess the knowledge among group IV staffs before and after the teaching programme, to assess the effectiveness of structured teaching programme among group IV staffs on breast self examination and to associate the post test knowledge score with the demographic variables. The study method was evaluative research approach and a pre experimental one group pre test and post test research design was used. Non randomized sampling technique was used to select the sample. The total sample was 30 group IV staffs. Pre test and post test scores was assessed by using structured questionnaires. The result of the study concluded that mean and standard deviation of knowledge level score in pre test was 3.8 and 1.76 and post test score was 12.5 and 2.24 the calculated ' $t$ 'value was 21.75 which reveals that there was statistically highly significant difference between the pre test and post test at $\mathrm{P}<0.05$. It is evidenced that the structured teaching programme was significantly effective in improving knowledge regarding breast self examination (BSE) among school teachers. Hence, the structured teaching programme regarding breast self examination among grade IV staffs is found effective.
\end{abstract}

Copyright@2017 V. Hemavathy et al. This is an open access article distributed under the Creative Commons Attribution License, which permits unrestricted use, distribution, and reproduction in any medium, provided the original work is properly cited.

\section{INTRODUCTION}

Breast self examination is a procedure performed by an individual to physically and visually examine herself for changes in the breast under arm areas of the body. Breast self examination is an important of component health promotion and maintenance. Providing education and encouraging the women to perform breast self examination is recommended to decrease the mortality rates from breast disorders. Breast self examination is a simple very low cost non-invasive comfortable, adjuvant screening.

\section{*Corresponding author: Hemavathy $\mathbf{V}$}

Dept of Mental Health Nursing Sree Balaji College of Nursing, Bharath University Tamil Nadu, India
It can be done by every women above 30 years, pregnant women, breast-feeding women and women with breast implants. There is an evidence woman who correctly practices breast self-examination monthly or more likely to detect lump at the early stages of its development and early diagnosis has been reported to influence early treatment and to yield a better survival rate.

\section{Objectives}

- To assess the level of knowledge regarding breast self examination before structured teaching programme among group IV staffs in selected hospitals. 
- To evaluate the effectiveness of structured teaching programme regarding breast self examination among house group IV staffs in selected hospitals.

- $\quad$ To compare pretest and post test knowledge after the structured teaching programme.

- To find out the association between the post test knowledge scores with selected demographic variables.

\section{METHODOLOGY}

Evaluative research approach and pre-experimental one group pre-test and post-test was adopted for the study. The research setting was at Sree Balaji Medical College and hospital, Chrompet, Chennai-44 and Sample size was 30 grade IV staffs selected by non-probality convenient sampling technique.

\section{RESULT}

In pre-test majority of the grade IV staffs reveals $23(76 \%)$ have inadequate knowledge, $7(24 \%)$ moderately adequate knowledge about breast self examination. reveals the postassessment scores of the grade IV staffs after the structured teaching programme on breast self examination. Regarding the post- assessment, majority of the grade IV staffs $16(53 \%)$ gained moderately adequate knowledge, $10(33 \%)$ gained adequate knowledge, 4(14\%) gained inadequate knowledge. The pre-test mean was 3.8 with standard deviation 1.76 , and the post-test mean score was 12.5 with standard deviation 2.24 the obtained paired ' $t$ ' value was 21.75 which reveals there was statistically highly significant difference between the pre-test and post-test at $\mathrm{P}<0.05$.
Hence, the structured teaching programme regarding breast self examination among grade IV staffs is found effective.

\begin{tabular}{cccccc}
\hline $\begin{array}{c}\text { Overall } \\
\text { knowledge }\end{array}$ & Mean & $\begin{array}{c}\text { Mean } \\
\text { difference }\end{array}$ & Sd & $\begin{array}{c}\text { 't' } \\
\text { value }\end{array}$ & $\begin{array}{c}\text { 'p' } \\
\text { Value }\end{array}$ \\
\hline PRE-TEST & 3.8 & 8.7 & 1.76 & & $\mathrm{P}<0.05$ \\
POST-TEST & 12.5 & & 2.24 & 21.75 & \\
\hline
\end{tabular}

\section{CONCLUSION}

The study concluded that majority of the grade IV staffs have gained moderately adequate knowledge on breast self examination. Furthermore the teaching programme was found to be effective as it has not only imparted knowledge but skills on how to perform breast self examination.

\section{References}

1. Frazer DM, Cooper MA.Myles textbook for midwives. $14^{\text {th }}$ ed.London:Churchill livingstone; 2001 .

2. Suzanne C. Smeltzer Brunda G.Bare. Brunner and Suddhartha's. Text book of medical and surgical nursing. New York; Lippincott William's company. 1992.

3. J.E.Duffy. Harrison's principles of internal medicine. $16^{\text {th }}$ ed. (vol.II) New York; Mc graw- Hill companies.

4. Joyce.M.black. Esther Matassarin. Jacobs. Luckmann. Sorensesn's. Medical Surgical Nursing. $4^{\text {th }}$ ed. Philadelphia; W.B. Saunders Company. 1993.

5. www.cinhal.com

Please cite this article in press as:

V. Hemavathy., Girijabhaskaran and Ningombam Rabita Devi (2017), A Study To Assess The Effectiveness of Structured Teaching Programme on Knowledge Regarding Breast Self Examination Among Grade Iv Staffs Working At Selected Hospital Chennai, International Journal of Current Advanced Research, 6(3), pp. 2347-2348. http://dx.doi.org/10.24327/ijcar.2017. 2348.0004 